\title{
STATUS MUTU PERAIRAN TELUK GORONTALO DENGAN MENGGUNAKAN METODE POLLUTION INDEX
}

\author{
Miftahul Khair Kadima,*, Nuralim Pasisingi ${ }^{\mathrm{a}}$ \\ aManajemen Sumberdaya Perairan, Fakultas Perikanan dan Ilmu Kelautan, Universitas Negeri Gorontalo, \\ Indonesia \\ *Corresponding author: miftahulkhairkadim@ung.ac.id
}

\begin{abstract}
Abstrak
Mutu kualitas air suatu perairan sangat penting untuk menopang kelulushidupan organisme di dalamnya. Sebagai suatu sistem akuatik, penentuan status mutu air perlu dilakukan guna menjadi acuan dalam melakukan pemantauan pencemaran kualitas air. Penelitian ini bertujuan untuk mengkaji status mutu air di perairan Teluk Gorontalo. Terdapat 5 stasiun pengamatan yang dipilih berdasarkan kondisi pantai dan karakteristik ekologi Teluk Gorontalo. Pengambilan sampel parameter kualitas air dilakukan di sepanjang perairan Teluk Gorontalo pada bulan Mei-Juli 2017. Prosedur pengambilan sampel berdasarkan metode baku APHA. Data kualitas air yang ada kemudian dianalisis dengan menggunakan Metode Indeks Pencemaran. Hasil penelitian menunjukkan bahwa Teluk Gorontalo memperoleh skor indeks pencemaran rata-rata 4,74. Hal ini menunjukkan status mutu Teluk Gorontalo di bulan Juni hingga Juli 2017 tergolong dalam kategori tercemar ringan.
\end{abstract}

Kata Kunci: Indeks Pencemaran, kualitas air, status mutu, Teluk Gorontalo

\begin{abstract}
Water quality is one of aspect which very important to support living organisms. Determination of water quality status needs to be carried out as a reference to monitor water pollution of an aquatic system. This study aimed to assess the status of water quality in Gorontalo Bay. There were 5 observation stations selected based on the coastal conditions and ecological characteristics. Sampling of water quality parameters was conducted along the Gorontalo Bay during period May to July 2017. Sampling procedure based on APHA standard method. The water quality data were analyzed using Pollution Indeks method. Gorontalo Bay has Pollution Index average score of 4.74. This value showed that the quality status of the Gorontalo Bay on June-July 2017 is considered as polluted category.
\end{abstract}

Keywords: Gorontlao Bay, pollution indeks, quality status, water quality

\section{PENDAHULUAN}

Laut adalah ruang wilayah lautan yang merupakan kesatuan geografis beserta segenap unsur terkait padanya yang batas dan sistemnya ditentukan berdasarkan aspek fungsional. Baku mutu air laut adalah ukuran batas atau kadar makhluk hidup, zat, energi, atau komponen yang ada atau harus ada dan/atau unsur pencemar yang ditenggang keberadaannya di da1am air laut. Status mutu laut adalah tingkatan mutu laut pada lokasi dan waktu tertentu yang dinilai berdasarkan baku mutu air laut dan/atau kriteria baku kerusakan laut. Perlindungan mutu laut adalah setiap upaya atau kegiatan yang dilakukan agar mutu laut tetap baik. Status mutu laut ditetapkan berdasarkan inventarisasi dan/atau penelitian data mutu air laut, kondisi tingkat kerusakan laut yang mempengaruhi mutu laut [1].

Teluk Gorontalo merupakan perairan yang masuk ke dalam wilayah administrasi Kota Gorontalo. Teluk ini memiliki sumberdaya perikanan dan kelautan yang tinggi karena secara geografis berada dalam bagian Teluk Tomini, Laut Sulawesi dan Zona 
Eksklusif Ekonomi [2]. Perairan Teluk Tomini dikenal relatif subur dan kaya akan potensi alam laut [3], selain itu juga dikenal sebagai daerah wisata bahari serta memiliki berbagai potensi sumberdaya ikan pelagis [4]. Kondisi ini menjadikan Teluk Gorontalo sebagai salah satu pusat aktivitas manusia sehingga memungkinkan terjadinya aktivitas pencemaran.

Polusi atau pencemaran lingkungan adalah masuknya atau dimasukkannya makhluk hidup, zat energi, dan atau komponen lain ke dalam lingkungan atau berubahnya tatanan lingkungan oleh kegiatan manusia atau oleh proses alam sehingga kualitas lingkungan turun sampai ke tingkat tertentu yang menyebabkan lingkungan menjadi kurang atau tidak dapat berfungsi lagi sesuai dengan peruntukannya [5]. Salah satu cara untuk mengontrol pencemaran suatu ekosistem dapat dilakukan dengan pemantauan kualitas air dalam jangka waktu tertentu, sehingga diketahui status mutu perairan tersebut. Apabila terjadi pencemaran segera dilakukan pencegahan dan penanggulangan sesuai tingkat pencemarannya [6]. Percemaran suatu ekosistem perairan bergantung pada kondisi lingkungannya. Keseimbangan ekosistem yang terpelihara dengan baik memberikan daur ulang ekosistem air berlangsung secara alamiah.

Indeks Kualitas Air merupakan suatu sistem perkiraan berupa indeks yang diperoleh dengan cara penggabungan parameter-parameter kualitas air dalam skala-skala tertentu yang kemudian dijadikan skala angka tunggal dengan metode perhitungan tertentu. Penerapan standar ini menjadi acuan dalam mengevaluasi kondisi air sehingga dapat diputuskan apakah air tersebut dapat digunakan atau tidak [7]. Metode indeks kualitas air yang paling banyak digunakan di Indonesia salah satunya yaitu metode Indeks Pencemaran (Pollution Index - PI).

Pengelolaan kualitas air atas dasar Indeks Pencemaran (IP) dapat memberi masukan pada pengambil keputusan agar dapat menilai kualitas badan air untuk suatu peruntukan serta melakukan tindakan untuk memperbaiki kualitas jika terjadi penurunan kualitas akibat kehadiran senyawa pencemar. Metode ini sudah diatur dan dituangkan dalam Keputusan Menteri Lingkungan Hidup Nomor 115 tahun 2003. Indeks ini dinyatakan sebagai Indeks Pencemaran (Pollution Index) yang digunakan untuk menentukan tingkat pencemaran relatif terhadap parameter kualitas air yang diizinkan [7].

Wilayah pesisir Teluk Gorontalo memberikan kontribusi besar untuk kegiatan perekonomian Provinsi Gorontalo. Berbagai macam kegiatan atau kepentingan ada di wilayah pesisir Teluk ini, seperti perikanan (penangkapan), pariwisata, pemukiman, maritim dan kegiatan pelabuhan. Selain itu Teluk Gorontalo juga menerima masukan dari muara Sungai Bone-Bolango. Tingginya aktivitas manusia yang ada di Teluk Gorontalo dikhawatirkan akan memberikan dampak pencemaran terhadap kondisi kualitas air teluk tersebut, oleh karenanya diperlukan adanya pemantauan status mutu perairan. Penelitian ini bertujuan untuk mengkaji status mutu air di perairan Teluk Gorontalo berdasarkan Metode Indeks Pencemaran (IP). Penentuan status mutu air dengan metode IP ini dimaksudkan sebagai acuan dalam melakukan pemantauan kualitas air suatu sistem akuatik.

\section{MATERI DAN METODE}

Lokasi penelitan mencakup wilayah sepanjang pesisir Teluk Gorontalo. Teluk 
ini masuk wilayah administrasi dari kota Gorontalo. Lokasi pengambilan sampel dilakukan pada 5 stasiun pengamatan, penentuan stasiun secara purposive sampling berdasarkan aktivitas, kondisi pantai dan karakteristik ekologi Teluk Gorontalo (lihat Gambar 1). Stasiun 1 terletak di Desa Tanjung Kramat, merupakan lokasi yang dekat dengan permukiman nelayan. Stasiun 2 berada di wilayah Kelurahan Pohe, tidak terdapat aktivitas disini karena pantai berbatasan langsung dengan tebing. Stasiun 3 merupakan wilayah laut yang dekat dengan muara Sungai Bone-Bolango. Stasiun 4 berada di wilayah Kelurahan Talumolo dan dekat dengan pelabuhan kontainer. Stasiun 5 berada di wilayah Kelurahan Leato, merupakan daerah dekat dengan pemukiman padat..

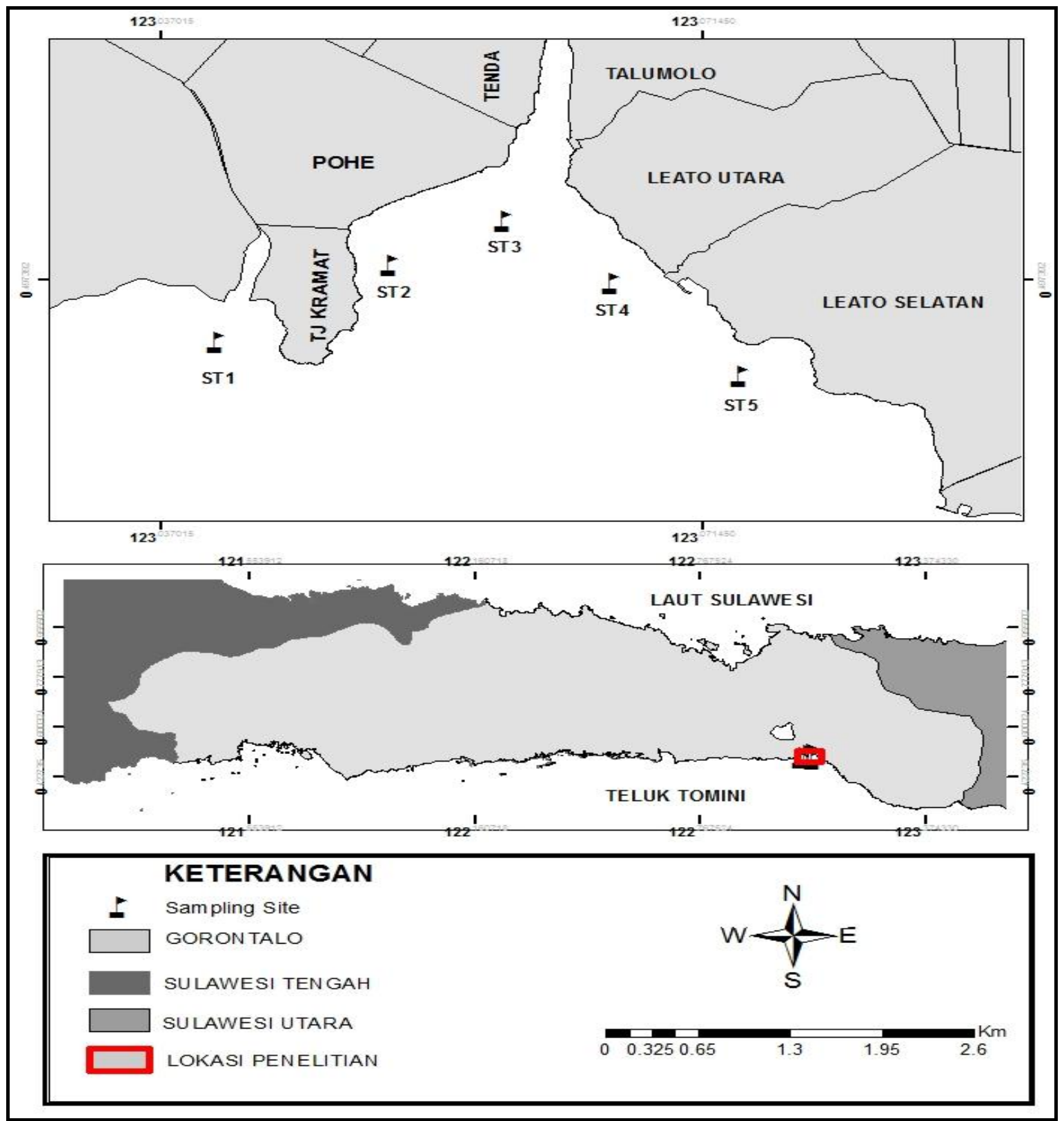

Gambar 1. Peta Lokasi Penelitian 


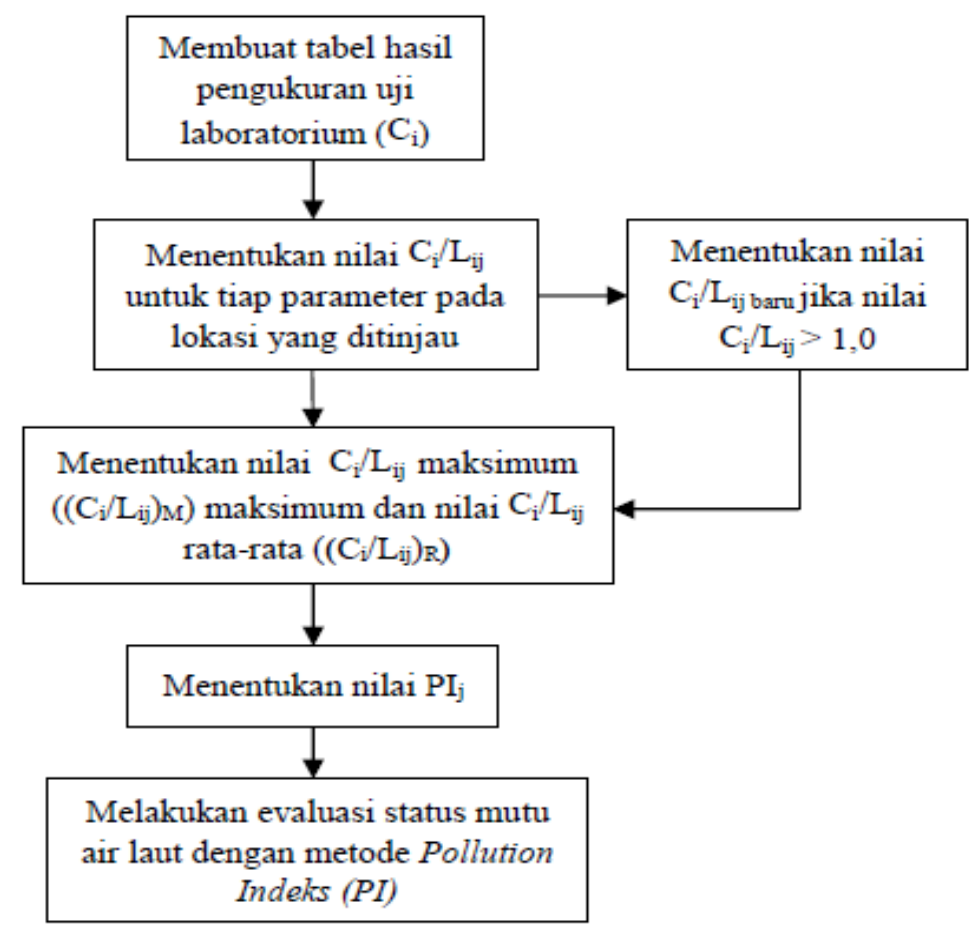

Gambar 2. Alur Perhitungan Metode Indeks Pencemaran

Pengambilan sampel parameter kualitas air dilakukan di sepanjang perairan Teluk Gorontalo pada bulan MeiJuli. Adapun parameter kualitas air yang diukur yaitu Suhu, pH, salinitas, Oksigen Terlarut, Amonium nitrogen, Nitrat dan Ortofosfat, serta klorofil-a sebagai penunjang untuk melihat kondisi kesuburan perairan. Prosedur pengambilan sampel berdasarkan metode baku APHA [8]. Data kualitas air yang ada kemudian akan dianalisis dengan menggunakan Metode Indeks Pencemaran (IP) [9] dengan membandingkan nilai parameter kualitas air dengan baku mutu air [10]. Alur Perhitungan Metode Indek Pencemaran [7] dapat dilihat pada (Gambar 2).

\section{HASIL DAN PEMBAHASAN}

Kualitas air laut yang digunakan untuk biota laut dan aktivitas lain seperti wisata bahari maupun pelabuhan secara ideal harus memenuhi standar, baik secara fisik, kimia,dan biologi. Nilai kualitas air laut yang melampaui ambang batas maksimum untuk peruntukannya akan digolongkan sebagai air tercemar [11]. Hasil pengukuran parameter kualitas air di Teluk Gorontalo dapat dilihat pada (Tabel 1).

Tabel 1 menunjukkan bahwa suhu perairan Teluk Gorontalo tertinggi terletak di Stasiun 1 pada sampling 1 yaitu $29.8{ }^{\circ} \mathrm{C}$ dan terendah di Stasiun 3 pada sampling 3 yaitu $26.5{ }^{\circ} \mathrm{C}$. Konsentrasi oksigen terlarut (DO) tertinggi hasil analisis berada di Stasiun 4 pada sampling 1 dan terendah terletak di Stasiun 3 pada sampling 3 . Nilai $\mathrm{pH}$ antar stasiun tidak terlalu berbeda dengan kisaran antara 5.7 sampai 6.7. Sama halnya dengan kadar salinitas yang tidak banyak terdapat perbedaan antar stasiun dan antar sampling yang berkisar antara 31.2 sampai $35 \%$. Adapun konsentrasi $\mathrm{NO}_{3}$ tertinggi dan terendah sama-sama teramati pada pengambilan sampel 1, berturut-turut di stasiun 3 dengan konsentrasi $0.146 \mathrm{mg} / \mathrm{L}$ dan di stasiun 4 dengan konsentrasi $0.042 \mathrm{mg} / \mathrm{L}$. Kandungan $\mathrm{NH}_{3}$ tertinggi dan terendah 
teramati pada sampling 2 dengan nilai terendah $0.035 \mathrm{mg} / \mathrm{L}$ terletak di stasiun 4 dan nilai tertinggi $0.206 \mathrm{mg} / \mathrm{L}$ terletak di Stasiun 3. Adapun konsentrasi $\mathrm{PO}_{4}$ paling tinggi terdapat pada sampling 3 di stasiun 4 dengan nilai $3.744 \mathrm{mg} / \mathrm{L}$, sedangkan konsentrasi terendah terdapat pada sampling 2 di stasiun 5 dengan nilai $0.984 \mathrm{mg} / \mathrm{L}$.

Berdasarkan data dari lima stasiun (titik) pengamatan (Tabel 1), selanjutnya dilakukan perhitungan indeks kualitas air. Indeks Pencemaran membutuhkan nilai rata-rata semua nilai parameter yang diukur kemudian dicatat sebagai $\mathrm{Ci} / \mathrm{Lij}$. Nilai $\mathrm{Ci} / \mathrm{Lij}$ harus mencakup nilai maksimum dan tidak akan bermakna jika Ci/Lij bernilai $>1$. Tolak ukur pencemaran air jika nilai $(\mathrm{Ci} / \mathrm{LijR})$ atau (Ci/LijM) lebih besar dari 1,0, jika nilai $(\mathrm{Ci} / \mathrm{LijR})$ atau $(\mathrm{Ci} / \mathrm{LijM})$ semakin besar, maka tingkat pencemaran suatu badan air akan semakin besar pula. Hasil analisis sampel air laut Teluk Gorontalo dicatat sebagai $\mathrm{Ci}$ kemudian dibandingkan dengan standar baku mutu [10], yang dicatat sebagai Lij, sehingga dapat ditentukan nilai $\mathrm{Ci} / \mathrm{Lij}$ setiap parameter pada sampel air laut. Hasil analisis data pengukuran kualitas air dengan Metode Indek Pencemaran (PI) dapat dilihat pada Tabel 2 dan diagram skor mutu air laut Teluk Gorontalo pada (Gambar 3).

Hasil analisis data menggunakan metode Indeks Pencemaran di atas menunjukkan hasil yang berbeda-beda di setiap bulannya. Diketahui bulan Juni memiliki nilai skor Indkes Pencemaran (Pij) tertinggi (4,92) kemudian diikuti oleh bulan Juli $(4,82)$ dan Mei $(4,48)$. Jika dirata-ratakan $\left(\mathrm{PI}_{\mathrm{R}}\right)$ maka diperoleh skor 4,74 sehingga Perairan Teluk Gorontalo masuk dalam kategori Tercemar Ringan. Secara rinci dapat diamati pada masing-masing parameter pengukuran yang memberikan kontribusi terhadap skor Indeks Pencemaran. Nilai suhu, oksigen terlarut (DO), salinitas dan $\mathrm{NH}_{3}$ masih sesuai dengan baku mutu, sedangkan nilai $\mathrm{NO}_{3}, \mathrm{PO}_{4}$ dan $\mathrm{pH}$ sudah tidak sesuai dengan baku mutu yang diatur dalam KEPMEN-LH tahun 2004 untuk biota air. Derajat keasaman $(\mathrm{pH})$ merupakan salah satu parameter yang dapat menentukan produktivitas suatu perairan, dan $\mathrm{pH}$ yang ideal untuk kehidupan fitoplankton dalam perairan adalah 6,5-8,5 [12]. Derajat keasaman $(\mathrm{pH})$ adalah cerminan dari keasaman yang diukur dari jumlah ion hydrogen [13]. Nilai $\mathrm{pH}$ air akan mempengaruhi tingkat kesuburan perairan karena mempengaruhi kehidupan jasad renik [14]. Nilai $\mathrm{pH}$ yang ideal bagi perairan adalah 7 hingga 8,5. Kondisi perairan yang sangat basa maupun sangat asam akan membahayakan kelangsungan hidup organisme karena akan mengganggu proses metabolisme dan respirasi [15].

Suhu perairan yang bervariasi dipengaruhi oleh faktor lama penyinaran matahari. Menurut [14], suhu dapat mempengaruhi fotosintesis di laut secara langsung maupun tidak langsung. Pengaruh secara langsung yakni suhu berperan untuk mengontrol reaksi enzimatik fotosintesis. Suhu yang tinggi dapat menaikan laju maksimum fotosintesis, sedangkan pengaruh tidak langsung yakni dalam merubah struktur hidrologi kolom perairan yang pada gilirannya

Tabel 1. Hasil Pengukuran Parameter Kualitas Air di Teluk Gorontalo

\begin{tabular}{|c|c|c|c|c|c|c|c|c|c|c|c|c|c|c|c|c|c|}
\hline \multirow{3}{*}{ No. } & \multirow{3}{*}{ Parameter } & \multirow{3}{*}{ Satuan } & \multicolumn{15}{|c|}{ Hasil Pengamatan } \\
\hline & & & \multicolumn{5}{|c|}{ Sampling 1 (Mei) } & \multicolumn{5}{|c|}{ Sampling 2 (Juni) } & \multicolumn{5}{|c|}{ Sampling 3 (Juli) } \\
\hline & & & St 1 & St 2 & St 3 & St 4 & St 5 & St 1 & t $2^{S}$ & t $3^{S}$ & $\begin{array}{r}S \\
t 4^{S}\end{array}$ & $\begin{array}{l}\text { S } \\
\text { t } 5\end{array}$ & $\mathrm{t}^{\mathrm{S}}$ & t $2^{S}$ & t $3^{S}$ & $\begin{array}{r}S \\
t 4^{S}\end{array}$ & $\mathrm{t} 5^{S}$ \\
\hline \multicolumn{18}{|c|}{ A. Fisika } \\
\hline 1 & Suhu & ${ }^{\circ} \mathrm{C}$ & 29.8 & 29.7 & 28.4 & 29.1 & 29.5 & 29.4 & 28.2 & 26.7 & 28.3 & 26.8 & 29.6 & 28.4 & 26.5 & 27.3 & 28.4 \\
\hline \multicolumn{18}{|c|}{ B. Kimia } \\
\hline 2 & DO & ppm & 6 & 5.4 & 5.4 & 6.2 & 6.1 & 5.3 & 4.9 & 5.4 & 5.6 & 5.8 & 4.4 & 4.4 & 3.5 & 4.4 & 4.5 \\
\hline 3 & $\mathrm{pH}$ & - & 6 & 5.7 & 6 & 5.7 & 5.7 & 6 & 6 & 6 & 6 & 6.7 & 6 & 6 & 6 & 6 & 6 \\
\hline 4 & Salinitas & $\%$ & 34.8 & 34.1 & 34.6 & 35 & 34 & 32.7 & 32.4 & 31.5 & 31.9 & 30.9 & 32.4 & 33.1 & 33.6 & 31.5 & 31.1 \\
\hline 5 & $\mathrm{NO}_{3}$ & $\mathrm{mg} / \mathrm{L}$ & 0.058 & 0.060 & 0.146 & 0.042 & 0.084 & 0.089 & 0.132 & 0.079 & 0.098 & 0.126 & 0.061 & 0.051 & 0.084 & 0.117 & 0.144 \\
\hline 6 & $\mathrm{NH}_{3}$ & $\mathrm{mg} / \mathrm{L}$ & 0.057 & 0.069 & 0.142 & 0.117 & 0.122 & 0.130 & 0.063 & 0.206 & 0.035 & 0.105 & 0.051 & 0.073 & 0.193 & 0.054 & 0.336 \\
\hline 7 & $\mathrm{PO}_{4}$ & $\mathrm{mg} / \mathrm{L}$ & 0.026 & 0.057 & 0.038 & 0.024 & 0.044 & 0.003 & 0.046 & 0.013 & 0.024 & 0.006 & 0.059 & 0.052 & 0.094 & 0.137 & 0.088 \\
\hline
\end{tabular}


Tabel 1. Hasil Analisis Data Pengkukuran Kualitas Air dengan Metode Indek Pencemaran.

\begin{tabular}{lcccccccccccccc}
\hline & \multicolumn{1}{c}{ Marameter } & \multicolumn{1}{c}{ Mei } & \multicolumn{1}{c}{ Jampling } \\
\cline { 2 - 15 } & $\mathbf{C i}$ & $\mathbf{L i j}$ & $\mathbf{C i} / \mathbf{L i j}$ & $\begin{array}{c}\mathbf{C i} / \mathbf{L i j} \\
\text { baru }\end{array}$ & $\mathbf{C i}$ & $\mathbf{L i j}$ & $\mathbf{C i} / \mathbf{L i j}$ & $\begin{array}{c}\mathbf{C i} / \mathbf{L i j} \\
\text { baru }\end{array}$ & $\mathbf{C i}$ & $\mathbf{L i j}$ & $\mathbf{C i} / \mathbf{L i j}$ & $\begin{array}{c}\mathbf{C i} / \mathbf{L i j} \\
\text { baru }\end{array}$ \\
\hline Suhu & 29,30 & $28-30$ & 0,30 & 0,30 & 27,88 & $28-30$ & 1,12 & 1,12 & 28,04 & $28-30$ & 0,96 & 1,0 \\
$\mathrm{DO}$ & 5,82 & 5 & 0,12 & 0,12 & 5,40 & 5 & 0,16 & 0,16 & 4,24 & 5 & 0,28 & 0,3 \\
$\mathrm{Salinita}$ & 34,50 & $33-34$ & 2,00 & 2,51 & 31,88 & $33-34$ & 3,24 & 3,55 & 32,34 & $33-34$ & 2,32 & 2,83 \\
$\mathrm{pH}$ & 5,82 & $7-8.5$ & 2,57 & 3,05 & 6,14 & $7-8.5$ & 2,15 & 2,66 & 6,00 & $7-8.5$ & 2,33 & 2,84 \\
$\mathrm{NO}_{3}$ & 0,08 & 0,008 & 9,76 & 5,95 & 0,10 & 0,008 & 13,08 & 6,58 & 0,09 & 0,008 & 11,42 & 6,29 \\
$\mathrm{NH}_{3}$ & 0,10 & 0,3 & 0,34 & 0,34 & 0,11 & 0,3 & 0,36 & 0,36 & 0,14 & 0,3 & 0,47 & 0,5 \\
$\mathrm{PO}_{4}$ & 0,04 & 0,015 & 2,51 & 3,00 & 0,02 & 0,015 & 1,22 & 1,42 & 0,09 & 0,015 & 5,72 & 4,79 \\
\hline
\end{tabular}

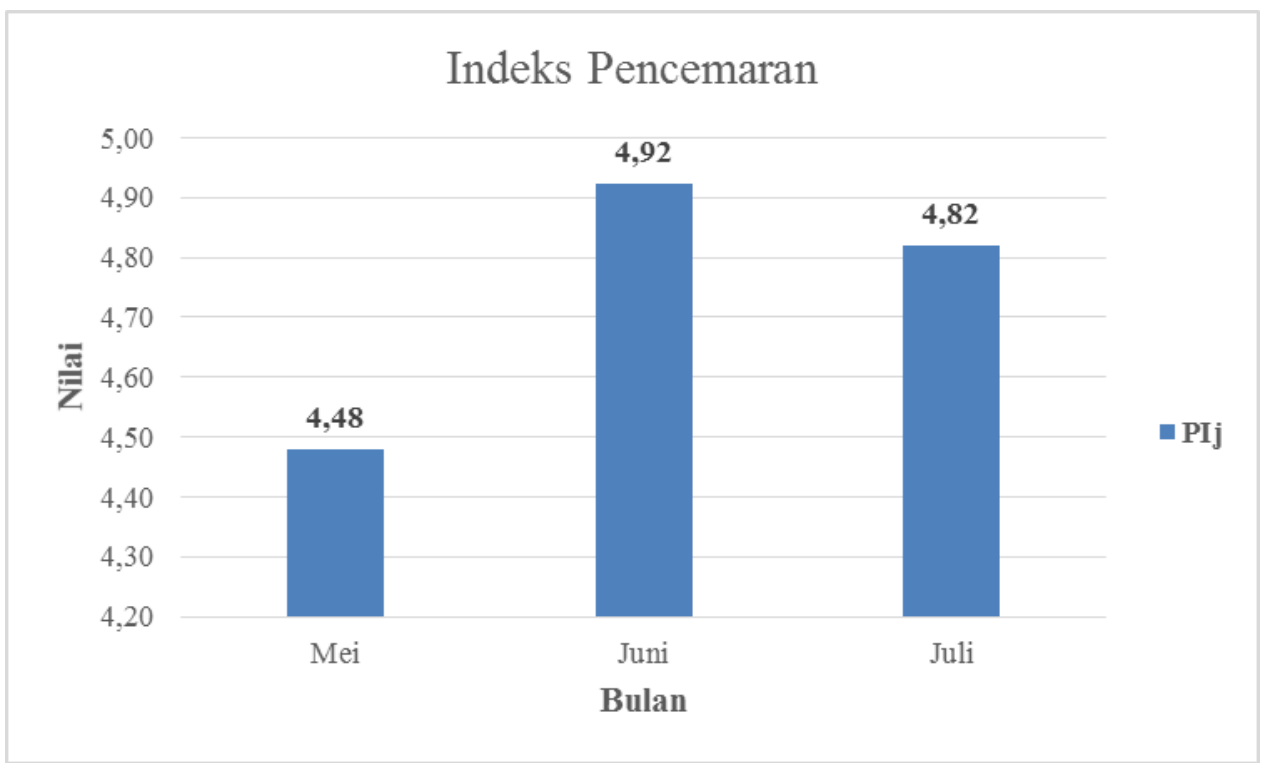

Gambar 3. Diagram Skor Air Laut Teluk Gorontalo

akan mempengaruhi distribusi fitoplankton. Menurut [16], kisaran suhu optimal bagi kehidupan ikan di perairan tropis adalah antara $28-32^{\circ} \mathrm{C}$.

Kandungan DO yang tinggi disebabkan kondisi pergerakan arus air yang tinggi sehingga difusi oksigen dari udara besar, berlaku juga sebaliknya. [17] menyebutkan bahwa pergerakan air memberikan peluang terjadinya difusi oksigen dari udara ke air. Menurut [18], kandungan oksigen dalam air yang ideal adalah antara 3-7 mg/l. Oksigen adalah unsur fital yang diperlukan oleh semua organisme untuk respirasi, termasuk di dalamnya fitoplankton, dan juga sebagai zat pembakar dalam proses metabolisme serta memiliki peran penting dalam proses penguraian bahan organik.

Salinitas perairan berada pada kisaran normal perairan teluk. Salinitas perairan dipengaruhi oleh pengadukan massa air dari bawah ke permukaan dan penyusupan massa air yang bersalinitas tinggi yang bergerak dari arah laut menuju pantai. Pola distribusi horizontal salinitas terlihat semakin dekat ke pantai nilai salinitas semakin rendah. Variasi salinitas dapat mempengaruhi kehidupan berbagai jenis plankton dalam suatu perairan. Diperairan pantai yang bersalinitas rendah komunitas plankton lebih tinggi dari pada perairan yang letaknya jauh dari pantai yang bersalinitas tinggi terutama dalam menentukan terjadinya suksesi jenisnya. 
Adapun nilai maksimal konsentrasi nutrient $\left(\mathrm{NO}_{3}\right.$ dan $\left.\mathrm{PO}_{4}\right)$ yang melebihi baku mutu mengindikasikan bahwa masukan bahan organik yang tinggi dari aktivitas daratan yang terbawa masuk melalui aliran sungai yang bermuara ke perairan teluk. [19] menyebutkan bahwa sungai merupakan salah satu ekosistem perairan mengalir yang berkontribusi membawa limbah yang berasal dari aktivitas daratan yang berpotensi mempengaruhi dan mengubah kondisi lingkungan perairan. [20] menyatakan bahwa kadar nitrat nitrogen pada perairan alami hampir tidak pernah lebih dari $0,1 \mathrm{mg} / \mathrm{l}$. Kadar nitrat lebih dari $5 \mathrm{mg} / \mathrm{l}$ menggambarkan terjadinya pencemaran anthropogenik yang berasal dari aktivitas manusia dan tinja hewan. Menurut UNESCO/WHO/UNEP (1992) dalam [20], kadar fosfor dalam perairan alami adalah berkisar antara $0.005-0.02 \mathrm{mg} / \mathrm{l}$ dalam bentuk fosfat. [18] menggolongkan perairan yang nilai fosfatnya lebih dari $0.1 \mathrm{mg} / \mathrm{l}$ adalah perairan eutrof, dimana perairan ini sering terjadi blooming fitoplankton. Thomas (1955) dalam [21], menyatakan bahwa fosfor menjadi faktor pembatas yang sangat penting di perairan produktif dan tidak produktif, fosfor memainkan peranan penting dalam determinasi jumlah fitoplankton

\section{KESIMPULAN}

Berdasarkan hasil analisis yang telah dilakukan dengan menggunakan metode Indeks Pencemaran, Teluk Gorotntalo di bulan Juni-Juli 2017 masuk ke dalam kategori tercemar ringan dengan skor $\mathrm{PI}_{\mathrm{R}} 4,74$.

\section{DAFTAR PUSTAKA}

[1] P. P. R. I. Nomor, "Tahun 1999 Tentang Pengendalian Pencemaran dan Kerusakan Laut," Sekr. Negara, vol. 9, 19.

[2] M. K. Kadim and S. Arsad, "Distribution And Abundance Of Microalgae Based On Coastal Characteristic And Ecology In Bone Bolango Coastal Region," Asian J.
Microbiol. Biotechnol. Environ. Sciense, vol. 18, no. 2, pp. 115-121, 2016.

[3] E. Yusron E., "Kondisi Perairan Dan Keanekaragaman Hayati Di Perairan Teluk Tomini Sulawesi Utara," Semin. Nas. Pendayagunaan Sumberd. Hayati Dalam Pengelolaan Lingkung., 2000.

[4] N. N. Wiadnyana, "Distribusi Dan Variasi Pigmen Fitoplankton Di Teluk Tomini, Sulawesi Utara," Semin. Kelaut. Ambon, pp. 248-259, 1998.

[5] U.-U. R. I. Nomor, "Tahun 1982 tentang Ketentuan-ketentuan Pokok Pengelolaan Lingkungan Hidup," Jkt. Kant. Menteri Negara Pembang. Dan Lingkung. Hidup, 4.

[6] B. C. Matahelumual, "Penentuan status mutu air dengan sistem STORET di Kecamatan Bantar Gebang," J Geol. Indones., vol. 2, no. 2, pp. 113-118, 2007.

[7] Verawati, "Analisis Kualitas Air Laut Di Teluk Lampung," Univ. Lampung Bandar Lampung, 2016.

[8] E. Rice, R. Baird, A. Eaton, and L. Clesceri, APHA (American Public Health Association): Standard method for the examination of water and wastewater. Washington DC (US): AWWA (American Water Works Association) and WEF (Water Environment Federation), 2012.

[9] K. N. L. Hidup, "Keputusan Menteri Negara Lingkungan Hidup Nomor 115 Tahun 2003 tentang Pedoman Penentuan Status Mutu Air," Jkt. Kementeri. Negara Lingkung. Hidup, 2003.

[10] K. L. Hidup, "Keputusan Menteri Negara Lingkungan Hidup Nomor 51 Tahun 2004 tentang Baku Mutu Air Laut," Jkt. MENKLH, 2004. 
[11] A. Fakhrunnisa, "Analisis Tingkat Pencemaran Air Laut Pada Kawasan Sekitar Pelabuhan Paotere," Univ. Hasanuddin Makassar, 2015.

[12] N. Pescod, "Investigation of Rational Effluent and Stream for Tropical Countries, Asian Institute of Technology," Bangk. Sgh, 1973.

[13] S. Andayani, "Manajemen Kualitas Air Untuk Budidaya Perairan," Univ. Brawijaya Malang, 2005.

[14] M. Kordi and A. B. Tancung, "Pengelolaan kualitas air dalam budidaya perairan," Rineka Cipta Jkt., 2007.

[15] T. A. Barus, "Pengantar limnologi," Univ. Sumat. Utara Medan, 2002.

[16] M. Kordi and A. B. Tancung, "Pengelolaan kualitas air dalam budidaya perairan," Rineka Cipta Jkt., 2007.
[17] M. Radwan, P. Willems, A. El-Sadek, and J. Berlamont, "Modelling of dissolved oxygen and biochemical oxygen demand in river water using a detailed and a simplified model," Int. J. River Basin Manag., vol. 1, no. 2, pp. 97-103, 2003.

[18] H. Subarijanti, "Pemupukan dan Kesuburan Perairan," Fak. Perikan. Univ. Brawijaya Malang, 2005.

[19] N. Pasisingi, N. T. Pratiwi, and M. Krisanti, "Kualitas perairan Sungai Cileungsi bagian hulu berdasarkan kondisi fisik-kimia," DEPIK J. IlmuIlmu Perair. Pesisir Dan Perikan., vol. 3, no. 1, 2014.

[20] H. Effendi, "Telaah kualitas air," Kanisius Yogyak., vol. 258, 2003.

[21] G. Hutchinson, "Introduction to lake biology and the limnoplankton. A treatise on Limnology, Vol. 2 John Wiley and Sons," Inc NY, vol. 1115, 1967. 